\title{
Livelihood assessment in district 1 of Medellin - Colombia
}

\begin{abstract}
The livelihood approach aims at the analysis, understanding and restrictions that the poorest people have to face in order to recover from difficult situations. The Department for International Development model is applied to an urban zone with the purpose of making an assessment of the livelihood of the district 'la Comuna 1' in Medellin, Colombia, which has been recognised as the poorest and one of the most dangerous districts of the city. The case study presents both a quantitative analysis (macro) and qualitative (micro) analysis, as a mixed method that allows a more complete analysis and understanding of livelihood, and providing a deeper understanding of the district from the livelihood approach. The results indicate a stable growth of livelihood during the period of analysis.
\end{abstract}

Keywords

Livelihood $\bullet$ poverty $\bullet$ human development $\bullet$ vulnerability $\bullet$ index $\bullet$ Medellin

(C) University of Warsaw - Faculty of Geography and Regional Studies
Ciro Alfonso Serna Mendoza, Miroslawa Czerny, Abraham Allec Londoño Pineda, Oscar Alonso Velez Rojas

Universidad de Manizales,

Director of the PhD program in Sustainable

Development,Columbia

redesomciro@hotmail.com

Faculty of Geography and Regional Studies, University of Warsaw, Poland

mczerny@uw.edu.pl

Coordinator of the International Relations and Business Group School as Economic

and Administrative Sciences,

Universidad de Medellin, Colombia.

alondono@udem.edu.co

Professor International Business,

Universidad de Medellin, Colombia

osvelez@udem.edu.co

Received: 26 June 2015

Accepted: 19 November 2015
Introduction

The livelihood approach aims to improve the understanding of the restrictions that the poorest people face through external shocks and difficulties, in order to recover from them and improve their capabilities, both in the present and the future without undermining basic resources (WCED 1987; UNDP 1992; Chambers \& Conway 1992; Scoones 1998; Carney et al 1999;. DIFD 1999).

The origin of this approach dates back to the considerations resulting from the Brundtland Report (1987), the Rio Conference (1992) and the seminal works of Chambers and Conway in 1992 (Krantz 2001). Their proposal was to go beyond the traditional notion of poverty, and has been associated with macroeconomic concepts presented in development theories that are linked exclusively with low-income countries (Foster \& Sen 1997). Instead, a vision of a multidimensional type is proposed, since poverty is manifested in different forms and is linked to a number of factors that affect families' livelihoods (Anand \& Sen 1997; Krantz 2001; Donohue \& Biggs 2015). For this paper, the poverty assessment is associated with a reduction in the livelihoods index, as presented when the index of sustainable livelihood and the types of capital show a value below 0.4 (see table 1 and table 2).

In the latest research works, livelihood has focused on identifying those assets that meet the needs of families, which can be both tangible and intangible (Chambers \& Conway 1992). Scoones (1998) made the first classification of the different types of capital that are required to meet the needs of poor people. These were: economic capital, financial capital, human capital, and natural capital; but its limitation is that, on the one hand, it was missing some forms of capital that occurred in the models of international institutions such as the UNDP, the CARE Foundation and the Department for International Development (DFID) (Krantz 2001). On the other hand, the fact is that in countries in Latin America, poverty is a phenomenon that affects not only rural areas but also cities and is due to the rapid growth of various urban areas, making the risks associated with conditions of poverty increase. (Pelling 2003; Bicknell et al. 2009; Rebotier 2012).

This work takes as its basis from the DFID model (1999), which is considered the most complete model so far, because it adds to the four known categories presented by Scoones (1998), an additional model called Physical Capital (Carney 1998; Solesbury 2003) and is applied to an urban zone model with the purpose making an assessment of the livelihood of the district "la Comuna 1" in Medellin, Colombia. The justification for both the city and "la Comuna 1" lies, in the first place, on the fact that Medellin has been experiencing a major transformation that began to materialize in 2003 with the construction of a series of building and infrastructure projects (Vélez 2015). Along with these there was also an innovations centre, international events, and the accelerated process in the innovation of information and communications technologies that gave it the City of the Year award in 2012 and 2015 by the Wall Street Journal. The selection of "La Comuna 1" was due to the fact that it is still the poorest district in the city (Alcaldia de Medellin 2013) and is precisely the type of area in which the livelihood approach can examine the different types of capital with which the poorest people can face adverse situations and, therefore, reduce their vulnerability. 
This work consists of three sections. In the first one, a case study of the district "Comuna 1" in Medellin and the main characteristics that justify its choice, is presented. The second section presents the methodology, which consists of two parts. The first is a quantitative type methodology based on data from the reports and surveys on quality of life provided by the Mayor of Medellin and the program "Medellin como vamos", or Medellin as we live, from which a multidimensional index of livelihood for the "La Comuna 1" is made. In order to do this, the DFID model (1999) is taken as the base. The second is the qualitative methodology related to the micro elements of the "La Comuna 1 ", which are necessary for the analysis of livelihoods, and which otherwise would be incomplete (Rebotier 2012; Carr 2014). This, then, is a mixed method that allows a more complete analysis of the livelihood of the selected area.

Finally, the analyses of the results are presented as the joint product of the quantitative analysis (macro) and qualitative analysis (micro). From these, the conclusions and the recommendations for future research are presented.

The district "Comuna 1" and the justification of the assessment of livelihood

In the 80s Medellin, was known throughout the world for being the hub of drug dealers that were seeking large incomes and who stained the city with blood: losing a whole generation of opportunities and development (El Espectador 2013). However, since 2003, the city has been undergoing a transformation that has been reinforced by various development plans, resulting in a series of buildings that has changed the face of the territory in which they were built, creating an inclusive community (Ruta N 2014; Forbes 2014; El Colombiano 2015a).

The most suitable word to describe this process of transformation is resilience, which is the ability to recover from adversity (IPCC 2014; CARE 2015). Indeed, to generate this transformation, the city had to recover from all the consequences of this dark period, including the fear that has left a culture of death since that time.

Nowadays this situation has changed considerably. The rate of homicides has been reduced from 381 homicides per 100,000 inhabitants in 1991, to 26.91 per 100,000 inhabitants in 2014 (BID 2008; El Colombiano 2015b). This is a result of the fact that the biggest drug dealers in the country have died due to government actions or have been sent to jail in other countries. This situation of fighting for territory and drug houses has diminished; however, a new phenomenon has arisen in recent years: drug microtrafficking, for which possible solutions are still being sought.

So far, Medellin is known by the world for its infrastructure transformation. However, very little has been written about the vulnerability that is suffered by the population in specific locations, areas and districts of the city. In this regard, Medellin consists of 6 zones, 16 districts and 249 neighbourhoods, as presented in figure 1.

The reason why it is necessary to look at development from a micro perspective is because this is where the real problems of people are found (Maxneef 2007), and also because the territory cannot be seen as the sum of activities promoted by the development of infrastructure, but by social construction as well (Lotero 2003).

In this work "La Comuna 1" was selected in the first place, because the drug dealers took advantage of the conditions of poverty that were present in many of the districts of Medellin. In fact, this was one of the most affected areas. The place was settled in the early 20th century by people who were mostly displaced by violence or due to the lack of housing, who would later occupy a large part of the territory on the hillsides of "La Comuna 1" (Comuna Popular 2014). The second reason is justified by the fact that it is

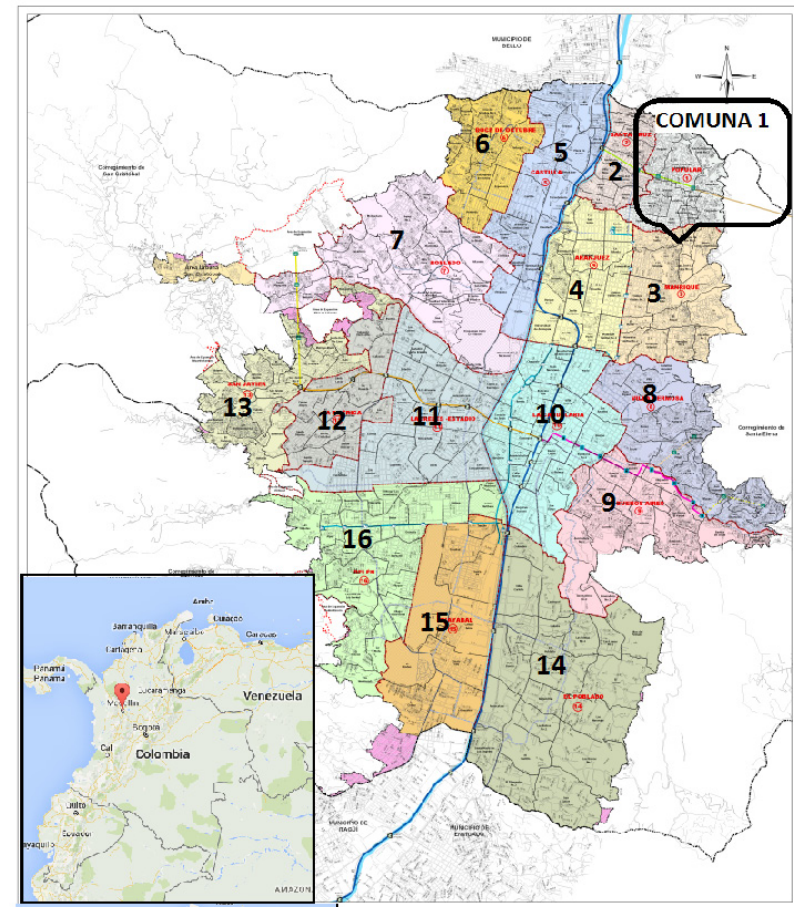

Figure 1. Zones, Districts and Neighbourhoods of Medellin Source: Based on Alcaldía de Medellin 2006.

the least developed area, and the poorest district in Medellin City (Alcaldía de Medellín 2013), meaning that it is the most vulnerable and therefore more difficult to secure livelihood: and this is why it is necessary for the place to have a livelihood assessment, since no work has been performed in this area.

Methodology for the assessment of livelihood in the district of "La Comuna 1" in Medellin, Colombia

Recent research on livelihood has turned to the themes of vulnerability and adaptive capacity (Romero et al. 2014). However, these had already been mentioned from the beginning of the theory. For example Chambers and Conway (1992) defined the theme related to impacts or external shocks as environmental sustainability, while the ability of people to face those threats was named social sustainability. More recently Rebotier (2012) and Carr (2014) considered that the risk could be perceived within the society. The first is associated with impacts from environmental variables and the second with the way society reacts to engage and, if necessary, to recover from such events.

To analyse both vulnerability and adaptive capacity requires the articulation of a series of variables of different types that are often very complex. For this reason it is necessary to use a more integrated and systemic approach (Scoones 1998; Fussel \& Klein 2006; Carr 2014; Londoño et al. 2015, Londoño 2015) to obtain a more complete livelihood assessment. To meet this purpose, this paper uses a methodology that combines both a quantitative and a qualitative method, which are described below.

\section{Quantitative Methodology}

Many researchers recommend that for a more holistic assessment, the use of composite indexes is needed. These tools help public policy makers to make an evaluation in a more comprehensive form, which facilitates at the same time structured decisions from highly technical levels (KEI 2005; Kondyli 2010; Kumar et al. 2012). 
Defining the units of analysis, dimensions and indicators

For this work, the data used for the assessment of sustainable livelihood includes the period between 2009 and 2013, with data available annually for this period. The justification for this lies in the fact that the first period of the transformation of Medellin was experienced between 2003 and 2008, but there is still the need for reliable data to ensure a better measurement process from that period (Scoones 1998; De la Espriella 2007; Schuschny \& Soto 2009). From 2009 until the present day, there is data available for both the quality of life report and the quality of life survey.

In the case of the dimensions, these refer to the five types of capital that are in the DFID model (1999): economic capital, financial capital, physical capital, human capital and social capital. These indicators are analysed in each dimension and provide the basis for the aggregation presented in the multidimensional index of livelihoods developed in this work.

Annex 1. Presents a summary of the criteria that justify the choice of the dimensions, required indicators and indicators that are available in both the report and the survey on quality of life.

With the indicators selected, the type of relationship that each one has with the general environment must be defined. For each indicator it is necessary to establish whether they have a positive or negative relationship regarding sustainable livelihoods. For this, the UNDP methodology for estimating the human development index is used.

If the relationship is positive, the formula used is: $f(X)=\frac{X-m}{M-m}$

If the relationship is negative the following equation is used: $f(x)=\frac{x-M}{m-M}$.

Where " $x$ " is the corresponding value of the variable or indicator for a given unit of analysis, in a given period of time. Likewise " $m$ " is the minimum value of the variable during the period studied, and " $M$ " the maximum value during the period mentioned (Sepulveda et al. 2005)

According to Sepulveda (2008), the aggregate index, or multidimensional livelihood, can be represented as follows: $I S L=\sum_{C=1}^{M}(\beta c / 100) * L c$. Where ISL is the multidimensional index of livelihood, $\beta c$ is the percentage of importance for each type of capital, and Lc is the average of the indicators for each type of capital.

In the case of disaggregated subindexes (Boogia \& Cortina 2010), those that are individually represented in each type of capital, the equation used is: $L c=\frac{1}{n c} \sum_{1}^{n c} I c$. Where Lc is the average of the indicators for each type of capital, "nc" the number of indicators that have evaluated the type of capital, and Ic is the capital type indicator.

The figure $\beta c$ indicates that the percentage of importance for each type of capital can be estimated by some weighting methodology such as: equiproportional weighting, participatory methods of weighting, calculations of regression, analysis of principal component, enclosures of data analysis, and processes using analytical hierarchy, among others (Schuschny \& Soto 2009). For this work the weight of each type of capital is set according to the number of indicators that it includes, so it is a variant of the equiproportional weighting methodology.

In this manner, 37 indicators were selected as follows: nine human capital, nine physical capital, eight financial capital, seven social capital and four for social capital. For the selection, two aspects were taken into consideration: first that the data for the indexes was available and the second that they were evaluated using the same methodology. It is important to point out that if these two criteria were not available the indicator was not selected.

As previously stated in the work, equiproportional weighting was used; therefore, the index depended on the quantity of indicators that were used. So the weight of each type of capital
Table 1. meaning of ISL index ranges

\begin{tabular}{|c|c|}
\hline Value of ILS & Interpretation \\
\hline $\mathrm{ISL}<0.2$ & Critical variation in livelihood \\
\hline $0.2<\mathrm{ISL}<0.4$ & Deterioration in livelihood \\
\hline $0.4<\mathrm{ISL}<0.6$ & Stable growth in livelihood \\
\hline $0.6<\mathrm{ISL}<0.8$ & Improvement of livelihood levels \\
\hline $\mathrm{ISL}>0.8$ & $\begin{array}{c}\text { Significant improvement of livelihood } \\
\text { levels }\end{array}$ \\
\hline
\end{tabular}

Source: Based on Sepùlveda et al (2005) and Sepulveda (2008)

results from dividing the number of indicators by the total of the indicators. In this manner, the weighting of each subindex is obtained by the percentage of dividing the number of variables of each capital, by the total number of variables, thus obtaining the following weightings: human capital 0.24 , physical capital 0.24 , financial capital 0.24 , social capital 0.19 and natural capital 0.11 . Following Sepulveda et al. (2005), the ranges shown in Table 1 for the value of ISL index are taken:

This quantitative methodology allows knowledge about the status of the livelihood of "La Comuna 1" using data from 2009 to 2013. Up to this point the model focuses on vulnerability, which is concentrated on the variables of the external environment; in other words it is the macro component of the assessment of sustainable livelihoods. However, this approach should be complemented by a micro perspective, because this is where the real problems of development takes place (Maxneef 2007). Following, is an alternative to microanalysis using a qualitative methodology.

\section{Qualitative Methodology}

The microanalysis of this study is based on official documentary sources, academic reports and testimonies from people living in this district, and is examined with reference to the considerations proposed by Carr (2014). In figure 2, the discourses of people, tools of coercion and levels of entrenchment of the identity of different groups are presented. In the elaboration of this analysis the following studies were considered: Ortiz (2011), Heinrichs and Bernet (2014), Alcaldía de Medellin (2009), IPC (2010), the Coorporación Convivamos, testimonies from Santa Cruz, Santo Domingo and the Popular neighbourhood, and professionals in development planning.

\section{Findings}

Macro Analysis: results of the index of sustainable livelihood for "La Comuna 1"

The index value of livelihood for the district "La Comuna 1" had a value of 0.52 which, according to table 2 , indicates that the period from 2009 until 2013 presented no major changes, either favourable or unfavourable.

The indexes that showed a stable performance for the period mentioned were human capital, physical capital, financial capital and natural capital, as shown in table 2; only social capital presents an improvement in livelihood levels.

According to annex 2 , the subindex with the best performance was social capital. The best results were presented in the Number of households participating in other types of programmes and 
MISCELLANEA GEOGRAPHICA - REGIONAL STUDIES ON DEVELOPMENT

Vol. $19 \cdot$ No. $4 \cdot 2015 \cdot$ pp. 9-20 • ISSN: 2084-6118 • DOI: 10.1515/mgrsd-2015-0025

Table 2. Index of sustainable livelihood

\begin{tabular}{|c|c|c|c|c|}
\hline \multicolumn{5}{|c|}{ Index of sustainable livelihood } \\
\cline { 1 - 3 } $\begin{array}{c}\text { Type of } \\
\text { capital }\end{array}$ & LC & Weight & Ponderation & \multirow{2}{*}{ ILS } \\
\hline Human & 0.48 & 0.24 & 0.12 & \multirow{2}{*}{0.52} \\
\cline { 1 - 3 } Physical & 0.53 & 0.24 & 0.13 & \multirow{2}{*}{0.10} \\
\cline { 1 - 3 } Financial & 0.47 & 0.22 & 0.12 & \\
\hline Social & 0.64 & 0.19 & 0.05 & \\
\hline Natural & 0.44 & 0.11 & & \\
\cline { 1 - 3 }
\end{tabular}

Source: Author's elaboration

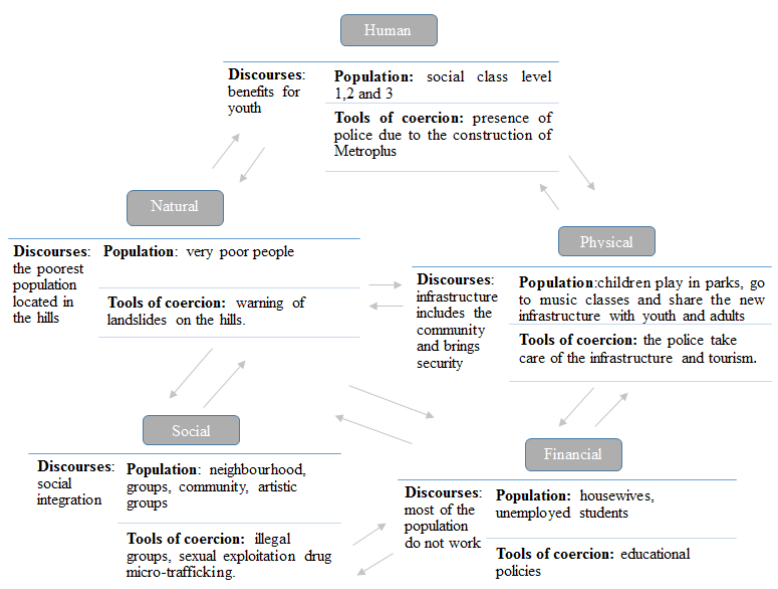

Figure 2. Microanalysis of the type of capitals Source: Author's elaboration based on Carr 2014

People affiliated with the subsidized health regime, with values of 0.72 and 0.71 respectively. Meanwhile, the lowest value corresponded to Number of households participating in music programmes with a value of 0.52 . In the Physical capital the subindex with the best performance was Phone Services with a value of 0.59 and the worst was Internet Services at 0.49 .

Regarding natural capital, there is no data available to allow better measurement, but there is an increase in the number of households that do not have certain services, with many of them burning their rubbish and cooking their food with unclean energy sources such as firewood and coal. This may be because many parts of "La Comuna 1" are hillside areas, where new people come to settle with no public services until legalized by the authorities. This problem also generates higher overcrowded areas, which represents a greater risk of landslides, because this phenomenon usually occurs in the upper parts of the city where the altitude reaches as high as 1900 meters above sea level.

In the finance capital there is an increase in homeownershipas a consequence, financial expenses have increased, therefore increasing the vulnerability associated with financial capital. However, the indicator with the lowest rating in this category was spending on medication, indicating that a large part of people's earnings is being earmarked to pay those costs with a direct link to the indicators of human capital, such as affiliation to the health system.
In the case of human capital, the indicator shows an improvement in the assets of the number of adults and children who go to bed hungry, but its major weaknesses are found in people who do not yet have membership for health and professional risks, this being evidence of unemployment.

Microanalysis: Discourses, enforcement mechanisms and communities inhabiting the area

Although the evaluation of indexes was done separately, in practice it must be noted that all these forms of capital interact with and impact upon each other. Indeed, the arrows in figure 2 indicate that relations can occur in several directions, since it is a system of livelihoods.

\section{Conclusion}

This work used a mixed methods approach to evaluate the livelihood assessment from a quantitative (Macro) perspective, based on the elaboration of an aggregated index and a series of subindexes. This allowed the identification of five types of capital, which was complemented with a qualitative (Micro) analysis, permitting a more complete understanding of livelihood in "La Comuna 1".

The aggregated index of livelihoods in "La Comuna 1" for the period 2009-2013 obtained a value of 0.52 , locating it in the category of Stable Growth of livelihood. When disaggregating the information, it is possible to see that the subindex with the best performance was Social capital, with a value of 0.64 . This indicates that in this type of capital there was an improvement in livelihoods, based on the citizens' participation in artistic, cultural and recreational activities, which is shown in the results from annex 2 and the qualitative analysis presented in figure 2 . However, the qualitative analysis is based on the local policies which must be oriented towards the weakest point, indicating the existence of illegal groups, drug micro-trafficking and sexual exploitation activities.

On the other hand, the subindex with the lowest performance was Natural capital which is located in the category of Stable Growth but presents a value of 0.44 . This is due to the fact that "La Comuna 1" is located on the hillsides of the city, where access for cleaning and rubbish disposal companies is very difficult, as in figure 2, which is why annexes 1 and 2 show problems relating to Rubbish Burning and Cleaning services. This shows the need for local policies to improve the cleaning services in this district of the city.

In the case of Human capital, the result presented in table 2 was 0.48 which, according to table 1 , indicates that the livelihood performance was stable. This annex shows a good performance in the following indexes: Hunger complaints in adults and Hunger complaints in children; however, the index related to Affiliates to the health system and Affiliates to occupational hazards, when analysed with the qualitative results, shows that most of the population of "La Comuna 1" belong to social levels 1, 2 and 3 . Based on these findings, local policies should be oriented to create better conditions in the health system.

According to table 1, financial capital also obtained a stable performance of livelihood at 0.47 . In annex 2, the Homeownership indicator presented a good performance of 0.62 ; however, the Financial expenses and Medication Expenses presented lows of 0.33 and 0.39 respectively, due to the fact that "La Comuna 1 " is a very poor and vulnerable community and local policies need to focus on different alternatives to generate income, provide jobs and make provisions for better access to housing and the health system.

Physical capital shows a stable improvement in the index in table 2 , obtaining a value of 0.53 , as well as in the indexes in 
annex 2 . When these results are compared with the qualitative results presented in figure 2 , it is possible to see that the infrastructure of "La Comuna 1" has been transformed, therefore significantly improving quality of life. Nowadays the community has parks for children, the "Biblioteca España" or "Spanish Library" and the Metrocable, constructions that began in 2003 and have transformed the face of Medellin.
Finally, future research should focus on deeper study using mixed methodologies, involving more participatory methods, where researchers can get direct contact with the different groups involved. This will allow for better and more realistic measurements of sustainable social transformation.

\section{Annex 1}

\begin{tabular}{|c|c|c|c|c|c|}
\hline Capital & Indicator & Variable & Justification & Data source & $\begin{array}{c}\text { Relationship } \\
\text { Orientation }\end{array}$ \\
\hline \multirow[t]{9}{*}{ Human } & $\begin{array}{l}\text { People over } 15 \\
\text { years who can } \\
\text { read and write }\end{array}$ & $\begin{array}{l}\text { Number of people who } \\
\text { cannot read under } 15 / \\
\text { under } 15 \text { years total }\end{array}$ & $\begin{array}{l}\text { Ability to do (Chambers } \\
\text { and Conway, 1992), } \\
\text { knowledge (Scoones, } \\
\text { 1998), knowledge and } \\
\text { skills (Elliot, 2008) }\end{array}$ & $\begin{array}{l}\text { Survey quality } \\
\text { of life Major of } \\
\text { Medellín }\end{array}$ & Positive \\
\hline & $\begin{array}{l}\text { People who are } \\
\text { not currently } \\
\text { studying }\end{array}$ & $\begin{array}{l}\text { Number of people } \\
\text { who are not studying/ } \\
\text { Under } 15 \text { years total }\end{array}$ & $\begin{array}{c}\text { Abilities and knowledge } \\
\text { (Scoones, 1998; Elliot, } \\
\text { 2008) }\end{array}$ & $\begin{array}{l}\text { Survey quality } \\
\text { of life Major of } \\
\text { Medellín }\end{array}$ & Positive \\
\hline & $\begin{array}{c}\text { Affiliates to health } \\
\text { system }\end{array}$ & $\begin{array}{l}\text { Number of people } \\
\text { non-affiliated / total } \\
\text { population of the } \\
\text { Comuna } 1\end{array}$ & $\begin{array}{l}\text { Good Health Conditions } \\
\text { (Sccones, 1998; Elliot, } \\
\text { 2008); equity (Chambers } \\
\text { and Conway, 1991) }\end{array}$ & $\begin{array}{l}\text { Survey quality } \\
\text { of life Major of } \\
\text { Medellín }\end{array}$ & Positive \\
\hline & $\begin{array}{c}\text { Affiliates to health } \\
\text { system }\end{array}$ & $\begin{array}{c}\text { Number of people in } \\
\text { the tax regime / Total } \\
\text { population of Comuna } \\
1\end{array}$ & $\begin{array}{l}\text { Good Health Conditions } \\
\text { (Sccones, 1998; Elliot, } \\
\text { 2008); equity (Chambers } \\
\text { and Conway, 1991) }\end{array}$ & $\begin{array}{l}\text { Survey quality } \\
\text { of life Major of } \\
\text { Medellín }\end{array}$ & Negative \\
\hline & $\begin{array}{l}\text { Affiliates } \\
\text { occupational } \\
\text { hazards }\end{array}$ & $\begin{array}{c}\text { Number of people } \\
\text { non- affiliated to } \\
\text { occupational hazards / } \\
\text { total population }\end{array}$ & $\begin{array}{l}\text { Good Health Conditions } \\
\text { (Sccones, 1998; Elliot, } \\
\text { 2008); equity (Chambers } \\
\text { and Conway, 1991) }\end{array}$ & $\begin{array}{l}\text { Survey quality } \\
\text { of life Major of } \\
\text { Medellín }\end{array}$ & Positive \\
\hline & $\begin{array}{c}\text { People with limited } \\
\text { walking }\end{array}$ & $\begin{array}{c}\text { Number of people with } \\
\text { limitations to walk/total } \\
\text { population }\end{array}$ & $\begin{array}{l}\text { Good Health Conditions } \\
\text { (Sccones, 1998; Elliot, } \\
\text { 2008); equity (Chambers } \\
\text { and Conway, 1991) }\end{array}$ & $\begin{array}{l}\text { Survey quality } \\
\text { of life Major of } \\
\text { Medellín }\end{array}$ & Positive \\
\hline & $\begin{array}{c}\text { People limited to } \\
\text { use their legs and } \\
\text { arms }\end{array}$ & $\begin{array}{c}\text { Number of people } \\
\text { with limitations to use } \\
\text { their arms or legs/total } \\
\text { population }\end{array}$ & $\begin{array}{l}\text { Good Health Conditions } \\
\text { (Sccones, 1998; Elliot, } \\
\text { 2008); equity (Chambers } \\
\text { and Conway, 1991) }\end{array}$ & $\begin{array}{l}\text { Survey quality } \\
\text { of life Major of } \\
\text { Medellín }\end{array}$ & Negative \\
\hline & $\begin{array}{c}\text { Complaints of } \\
\text { hunger in children }\end{array}$ & $\begin{array}{c}\text { Number of children } \\
\text { who complained of } \\
\text { hunger/total population }\end{array}$ & $\begin{array}{c}\text { Complaints (Swift.1989; } \\
\text { Chambers and Conway, } \\
\text { 1992) }\end{array}$ & $\begin{array}{l}\text { Survey quality } \\
\text { of life Major of } \\
\text { Medellín }\end{array}$ & Negative \\
\hline & $\begin{array}{l}\text { Decreased of } \\
\text { meals for children }\end{array}$ & $\begin{array}{l}\text { Number of people } \\
\text { who reported reducing } \\
\text { overall food from } \\
\text { their children/Total } \\
\text { population }\end{array}$ & $\begin{array}{c}\text { Complaints (Swift.1989; } \\
\text { Chambers and Conway, } \\
\text { 1992) }\end{array}$ & $\begin{array}{l}\text { Survey quality } \\
\text { of life Major of } \\
\text { Medellín }\end{array}$ & Negative \\
\hline Physical & Type of housing & $\begin{array}{c}\text { Number of people who } \\
\text { live in a lean to/Total of } \\
\text { houses }\end{array}$ & $\begin{array}{l}\text { Assets and resources } \\
\text { in a home (ECLAC, } \\
\text { 2007), 'risk factor of the } \\
\text { space (Rebotier, 2012), } \\
\text { housing conditions } \\
\text { (Romero et al. 2014) }\end{array}$ & $\begin{array}{l}\text { Survey quality } \\
\text { of life Major of } \\
\text { Medellín }\end{array}$ & Positive \\
\hline
\end{tabular}


Annex 1

\begin{tabular}{|c|c|c|c|c|c|}
\hline Capital & Indicator & Variable & Justification & Data source & $\begin{array}{l}\text { Relationship } \\
\text { Orientation }\end{array}$ \\
\hline & $\begin{array}{c}\text { Predominant } \\
\text { housing material }\end{array}$ & $\begin{array}{l}\text { Number of homes built } \\
\text { with adobe brick or } \\
\text { revoked/Total houses }\end{array}$ & $\begin{array}{c}\text { The unit of analysis is } \\
\text { the home (Cambers and } \\
\text { Conway, 1991; CEPAL, } \\
\text { 2007) }\end{array}$ & $\begin{array}{l}\text { Survey quality } \\
\text { of life Major of } \\
\text { Medellín }\end{array}$ & Negative \\
\hline & $\begin{array}{c}\text { Predominant } \\
\text { material on the } \\
\text { floors of the house }\end{array}$ & $\begin{array}{c}\text { Number of houses } \\
\text { using tiles/total houses }\end{array}$ & $\begin{array}{c}\text { The unit of analysis is } \\
\text { the home (Cambers and } \\
\text { Conway, 1991; CEPAL, } \\
\text { 2007) }\end{array}$ & $\begin{array}{l}\text { Survey quality } \\
\text { of life Major of } \\
\text { Medellín }\end{array}$ & Negative \\
\hline & Water supplier & $\begin{array}{l}\text { Homes that use water } \\
\text { from a service entity } \\
\text { provider/Total houses }\end{array}$ & $\begin{array}{l}\text { Water supply (Elliot, } \\
\text { 2007) }\end{array}$ & $\begin{array}{l}\text { Survey quality } \\
\text { of life Major of } \\
\text { Medellín }\end{array}$ & Negative \\
\hline & Energy services & $\begin{array}{c}\text { Number of houses with } \\
\text { energy supply/Total } \\
\text { household }\end{array}$ & $\begin{array}{c}\text { Equity and sustainability } \\
\text { (Chambres and } \\
\text { Conway, 1992), basic } \\
\text { infrastructure (Scoones, } \\
\text { 1998), water supply } \\
\text { (Elliot, 2007) }\end{array}$ & $\begin{array}{l}\text { Survey quality } \\
\text { of life Major of } \\
\text { Medellín }\end{array}$ & Negative \\
\hline & Aqueduct services & $\begin{array}{l}\text { Number of houses with } \\
\text { aqueduct services/ } \\
\text { Total houses }\end{array}$ & $\begin{array}{l}\text { Equity and sustainability } \\
\text { (Chambres and } \\
\text { Conway, 1992), basic } \\
\text { Infrastructure (Scoones, } \\
\text { 1998), water supply } \\
\text { (Elliot, 2007) }\end{array}$ & $\begin{array}{l}\text { Survey quality } \\
\text { of life Major of } \\
\text { Medellín }\end{array}$ & Negative \\
\hline & Phone Services & $\begin{array}{c}\text { Number of houses with } \\
\text { phone services/Total } \\
\text { houses }\end{array}$ & $\begin{array}{l}\text { Equity and sustainability } \\
\text { (Chambres and } \\
\text { Conway, 1992), basic } \\
\text { Infrastructure (Scoones, } \\
\text { 1998), access to } \\
\text { information (Elliot, } \\
\text { 2007) }\end{array}$ & $\begin{array}{l}\text { Survey quality } \\
\text { of life Major of } \\
\text { Medellín }\end{array}$ & Negative \\
\hline & Internet services & $\begin{array}{c}\text { Number of houses with } \\
\text { internet /Total houses }\end{array}$ & $\begin{array}{l}\text { Equity and sustainability } \\
\text { (Chambres and } \\
\text { Conway, 1992), basic } \\
\text { infrastructure (Scoones, } \\
\text { 1998), access to } \\
\text { information (Elliot, } \\
\text { 2007) }\end{array}$ & $\begin{array}{l}\text { Survey quality } \\
\text { of life Major of } \\
\text { Medellín }\end{array}$ & Negative \\
\hline & Cleaning services & $\begin{array}{c}\text { Number of houses with } \\
\text { cleaning services/Total } \\
\text { houses }\end{array}$ & $\begin{array}{c}\text { Equity and sustainability } \\
\text { (Chambres and } \\
\text { Conway, 1992), basic } \\
\text { infrastructure (Scoones, } \\
\text { 1998), access to } \\
\text { sanitation (Elliot, 2007) }\end{array}$ & $\begin{array}{l}\text { Survey quality } \\
\text { of life Major of } \\
\text { Medellín }\end{array}$ & Negative \\
\hline \multirow[t]{2}{*}{ Financial } & Homeownership & $\begin{array}{c}\text { Number of household } \\
\text { that own their homes / } \\
\text { Total household }\end{array}$ & $\begin{array}{c}\text { The unit of analysis is } \\
\text { the household (Cambers } \\
\text { and Conway, 1991; } \\
\text { ECLAC, 2007) }\end{array}$ & $\begin{array}{l}\text { Survey quality } \\
\text { of life Major of } \\
\text { Medellín }\end{array}$ & Negative \\
\hline & $\begin{array}{l}\text { Number of } \\
\text { vehicles }\end{array}$ & $\begin{array}{l}\text { Number of homes } \\
\text { with vehicles /Total } \\
\text { housedold }\end{array}$ & $\begin{array}{l}\text { Capital base (Scoones, } \\
\text { 1998), Assets and } \\
\text { resources in the } \\
\text { home (CEPAL, 2007), } \\
\text { access to financial } \\
\text { resources(Elliot, 2008) }\end{array}$ & $\begin{array}{l}\text { Survey quality } \\
\text { of life Major of } \\
\text { Medellín }\end{array}$ & Negative \\
\hline
\end{tabular}


Annex 1

\begin{tabular}{|c|c|c|c|c|c|}
\hline Capital & Indicator & Variable & Justification & Data source & $\begin{array}{l}\text { Relationship } \\
\text { Orientation }\end{array}$ \\
\hline & $\begin{array}{l}\text { Number of } \\
\text { motorcycles }\end{array}$ & $\begin{array}{c}\text { Number of homes with } \\
\text { motorcycles /Total } \\
\text { household }\end{array}$ & $\begin{array}{l}\text { Capital base (Scoones, } \\
\text { 1998), Assets and } \\
\text { resources in the } \\
\text { home (CEPAL, 2007), } \\
\text { access to financial } \\
\text { resources(Elliot, 2008) }\end{array}$ & $\begin{array}{l}\text { Survey quality } \\
\text { of life Major of } \\
\text { Medellín }\end{array}$ & Negative \\
\hline & $\begin{array}{l}\text { Job of the } \\
\text { householder }\end{array}$ & \begin{tabular}{|c|} 
Number of houses \\
where the householder \\
works/Total household
\end{tabular} & $\begin{array}{l}\text { Capital base (Scoones, } \\
\text { 1998), Assets and } \\
\text { resources in the } \\
\text { home (CEPAL, 2007), } \\
\text { access to financial } \\
\text { resources(Elliot, 2008) }\end{array}$ & $\begin{array}{l}\text { Survey quality } \\
\text { of life Major of } \\
\text { Medellín }\end{array}$ & Negative \\
\hline & $\begin{array}{l}\text { Financial } \\
\text { expenses }\end{array}$ & $\begin{array}{c}\text { Number of households } \\
\text { that allocate income } \\
\text { to financial expenses/ } \\
\text { Total household }\end{array}$ & $\begin{array}{l}\text { Capital base (Scoones, } \\
\text { 1998), Assets and } \\
\text { resources in the } \\
\text { home (CEPAL, 2007), } \\
\text { access to financial } \\
\text { resources(Elliot, 2008) }\end{array}$ & $\begin{array}{l}\text { Survey quality } \\
\text { of life Major of } \\
\text { Medellín }\end{array}$ & Positive \\
\hline & $\begin{array}{l}\text { Medical services } \\
\text { expenses }\end{array}$ & $\begin{array}{c}\text { Number of households } \\
\text { that spend income on } \\
\text { medical expenses/ } \\
\text { Total household }\end{array}$ & $\begin{array}{l}\text { Capital base (Scoones, } \\
\text { 1998), Assets and } \\
\text { resources in the } \\
\text { home (CEPAL, 2007), } \\
\text { access to financial } \\
\text { resources(Elliot, 2008) }\end{array}$ & $\begin{array}{l}\text { Survey quality } \\
\text { of life Major of } \\
\text { Medellín }\end{array}$ & Positive \\
\hline & $\begin{array}{l}\text { Medication } \\
\text { expenses }\end{array}$ & $\begin{array}{c}\text { Number of households } \\
\text { that allocate income } \\
\text { to medicine/ Total } \\
\text { household }\end{array}$ & $\begin{array}{l}\text { Capital base (Scoones, } \\
\text { 1998), Assets and } \\
\text { resources in the } \\
\text { home (CEPAL, 2007), } \\
\text { access to financial } \\
\text { resources(Elliot, 2008) }\end{array}$ & $\begin{array}{l}\text { Survey quality } \\
\text { of life Major of } \\
\text { Medellín }\end{array}$ & Positive \\
\hline & Pensions affiliation & $\begin{array}{l}\text { Number of homes non- } \\
\text { affiliated to pensions/ } \\
\text { total household }\end{array}$ & $\begin{array}{c}\text { Sustainability } \\
\text { (Chambres and Conway, } \\
\text { 1991) }\end{array}$ & $\begin{array}{l}\text { Survey quality } \\
\text { of life Major of } \\
\text { Medellín }\end{array}$ & Negative \\
\hline \multirow[t]{3}{*}{ Social } & $\begin{array}{c}\text { People affiliated } \\
\text { with the subsidized } \\
\text { health regime }\end{array}$ & $\begin{array}{l}\text { Number of people } \\
\text { affiliated with the } \\
\text { subsidized health } \\
\text { regime/ Total } \\
\text { population }\end{array}$ & $\begin{array}{c}\text { Sustainability } \\
\text { (Chambres and Conway, } \\
\text { 1991) }\end{array}$ & $\begin{array}{l}\text { Survey quality } \\
\text { of life Major of } \\
\text { Medellín }\end{array}$ & Positive \\
\hline & $\begin{array}{l}\text { Households } \\
\text { participating } \\
\text { in sports } \\
\text { programmes }\end{array}$ & $\begin{array}{c}\text { Number of households } \\
\text { participating in sports } \\
\text { programmes }\end{array}$ & $\begin{array}{l}\text { The unit of analysis is } \\
\text { the home (Cambers and } \\
\text { Conway, 1991; CEPAL, } \\
\text { 2007), participative } \\
\text { networks (CEPAL, } \\
\text { 2007), formal and } \\
\text { informal relationship } \\
\text { (Elliot, 2008) }\end{array}$ & $\begin{array}{l}\text { Survey quality } \\
\text { of life Major of } \\
\text { Medellín }\end{array}$ & Negative \\
\hline & $\begin{array}{l}\text { Number of } \\
\text { Households } \\
\text { participating } \\
\text { in recreational } \\
\text { programmes }\end{array}$ & $\begin{array}{c}\text { Number of Households } \\
\text { participating in } \\
\text { recreational programs }\end{array}$ & $\begin{array}{l}\text { The unit of analysis is } \\
\text { the home (Cambers and } \\
\text { Conway, 1991; CEPAL, } \\
\text { 2007), participative } \\
\text { networks (CEPAL, } \\
\text { 2007), formal and } \\
\text { informal relationship } \\
\text { (Elliot, 2008) }\end{array}$ & $\begin{array}{l}\text { Survey quality } \\
\text { of life Major of } \\
\text { Medellín }\end{array}$ & Negative \\
\hline
\end{tabular}




\section{Annex 1}

\begin{tabular}{|c|c|c|c|c|c|}
\hline Capital & Indicator & Variable & Justification & Data source & $\begin{array}{c}\text { Relationship } \\
\text { Orientation }\end{array}$ \\
\hline & $\begin{array}{c}\text { Number of } \\
\text { Households } \\
\text { participating in } \\
\text { music programmes }\end{array}$ & $\begin{array}{c}\text { Number of Households } \\
\text { participating in music } \\
\text { programmes }\end{array}$ & $\begin{array}{l}\text { The unit of analysis is } \\
\text { the home (Cambers and } \\
\text { Conway, 1991; CEPAL, } \\
\text { 2007), participative } \\
\text { networks (CEPAL, } \\
\text { 2007), formal and } \\
\text { informal relationship } \\
\text { (Elliot, 2008) }\end{array}$ & $\begin{array}{c}\text { Survey quality } \\
\text { of life Major of } \\
\text { Medellín }\end{array}$ & Negative \\
\hline & $\begin{array}{l}\text { Number of } \\
\text { Households } \\
\text { participating } \\
\text { in theatre } \\
\text { programmes }\end{array}$ & $\begin{array}{c}\text { Number of Households } \\
\text { participating in theatre } \\
\text { programmes }\end{array}$ & $\begin{array}{l}\text { The unit of analysis is } \\
\text { the home (Cambers and } \\
\text { Conway, 1991; CEPAL, } \\
\text { 2007), participative } \\
\text { networks (CEPAL, } \\
\text { 2007), formal and } \\
\text { informal relationship } \\
\text { (Elliot, 2008) }\end{array}$ & $\begin{array}{c}\text { Survey quality } \\
\text { of life Major of } \\
\text { Medellín }\end{array}$ & Negative \\
\hline & $\begin{array}{l}\text { Number of } \\
\text { Households } \\
\text { participating } \\
\text { in painting } \\
\text { programmes }\end{array}$ & $\begin{array}{c}\text { Number of Households } \\
\text { participating in painting } \\
\text { programmes }\end{array}$ & $\begin{array}{l}\text { The unit of analysis is } \\
\text { the home (Cambers and } \\
\text { Conway, 1991; CEPAL, } \\
\text { 2007), participative } \\
\text { networks (CEPAL, } \\
\text { 2007), formal and } \\
\text { informal relationship } \\
\text { (Elliot, 2008) }\end{array}$ & $\begin{array}{c}\text { Survey quality } \\
\text { of life Major of } \\
\text { Medellín }\end{array}$ & Negative \\
\hline & $\begin{array}{l}\text { Number of } \\
\text { Households } \\
\text { participating in } \\
\text { other types of } \\
\text { programme }\end{array}$ & $\begin{array}{c}\text { Number of Households } \\
\text { participating in other } \\
\text { types of programme }\end{array}$ & $\begin{array}{l}\text { The unit of analysis is } \\
\text { the home (Cambers and } \\
\text { Conway, 1991; CEPAL, } \\
\text { 2007), participative } \\
\text { networks (CEPAL, } \\
\text { 2007), formal and } \\
\text { informal relationship } \\
\text { (Elliot, 2008) }\end{array}$ & $\begin{array}{c}\text { Survey quality } \\
\text { of life Major of } \\
\text { Medellín }\end{array}$ & Negative \\
\hline \multirow[t]{4}{*}{ Natural } & $\begin{array}{l}\text { Households } \\
\text { without a toilet }\end{array}$ & $\begin{array}{c}\text { Number of households } \\
\text { without a toilet /Total } \\
\text { household }\end{array}$ & $\begin{array}{l}\text { Contamination } \\
\text { (Scoones, 1998) }\end{array}$ & $\begin{array}{c}\text { Survey quality } \\
\text { of life Major of } \\
\text { Medellín }\end{array}$ & Positive \\
\hline & Energy type & $\begin{array}{l}\text { Number of homes } \\
\text { where coal is used/ } \\
\text { Total households }\end{array}$ & $\begin{array}{c}\text { Pollution (Scoones, } \\
1998)\end{array}$ & $\begin{array}{c}\text { Survey quality } \\
\text { of life Major of } \\
\text { Medellín }\end{array}$ & Positive \\
\hline & Rubbish disposal & $\begin{array}{c}\text { Number of households } \\
\text { where rubbish } \\
\text { is burned/Total } \\
\text { household }\end{array}$ & $\begin{array}{c}\text { Pollution (Scoones, } \\
1998)\end{array}$ & $\begin{array}{c}\text { Survey quality } \\
\text { of life Major of } \\
\text { Medellín }\end{array}$ & Positive \\
\hline & Cleaning services & $\begin{array}{c}\text { Number of houses with } \\
\text { cleaning services/Total } \\
\text { household }\end{array}$ & $\begin{array}{c}\text { Pollution (Scoones, } \\
1998)\end{array}$ & $\begin{array}{c}\text { Survey quality } \\
\text { of life Major of } \\
\text { Medellín }\end{array}$ & Negative \\
\hline
\end{tabular}


Annex 2

\begin{tabular}{|c|c|c|c|c|c|c|c|c|c|c|}
\hline \multicolumn{11}{|c|}{ Index of sustainable livelihood for each type of capital } \\
\hline \multicolumn{11}{|c|}{ Human } \\
\hline Years & $\begin{array}{c}\text { People over } \\
15 \text { years } \\
\text { who can } \\
\text { read and } \\
\text { write }\end{array}$ & $\begin{array}{c}\text { People who } \\
\text { are not } \\
\text { currently } \\
\text { studying }\end{array}$ & $\begin{array}{c}\text { Affiliates to } \\
\text { health system }\end{array}$ & $\begin{array}{c}\text { Affiliates } \\
\text { to health } \\
\text { system }\end{array}$ & $\begin{array}{c}\text { Affiliates } \\
\text { occupa- } \\
\text { tional } \\
\text { hazards }\end{array}$ & $\begin{array}{c}\text { People } \\
\text { with limited } \\
\text { walking }\end{array}$ & $\begin{array}{l}\text { People } \\
\text { limited to } \\
\text { use their } \\
\text { legs and } \\
\text { arms }\end{array}$ & $\begin{array}{c}\text { Complaints } \\
\text { of hunger } \\
\text { in adults }\end{array}$ & $\begin{array}{c}\text { Complaints } \\
\text { of hunger } \\
\text { in children }\end{array}$ & LHC \\
\hline 2009 & 0.0634 & 0.7192 & 0.0258 & 0.1337 & 0.6337 & 0.0183 & 0.0101 & 0.2960 & 0.1821 & \\
\hline 2010 & 0.0572 & 0.7008 & 0.0202 & 0.1695 & 0.5507 & 0.0290 & 0.0179 & 0.3053 & 0.1778 & \\
\hline 2011 & 0.0487 & 0.7224 & 0.0234 & 0.1720 & 0.8851 & 0.0122 & 0.0095 & 0.3082 & 0.1606 & \\
\hline 2012 & 0.0559 & 0.7153 & 0.0446 & 0.2169 & 0.5576 & 0.0190 & 0.0138 & 0.2995 & 0.1401 & \\
\hline 2013 & 0.0701 & 0.7063 & 0.0230 & 0.2099 & 0.5617 & 0.0195 & 0.0138 & 0.1739 & 0.0914 & \\
\hline $\begin{array}{l}\text { Relation- } \\
\text { ship } \\
\text { Orien- } \\
\text { tation }\end{array}$ & Positive & Positive & Positive & Negative & Positive & Positive & Negative & Negative & Negative & 0.4786 \\
\hline Subindex & 0.4846 & 0.5561 & 0.2951 & 0.4387 & 0.2604 & 0.4398 & 0.4175 & 0.7645 & 0.6507 & \\
\hline $\mathbf{x}$ & 0.0591 & 0.7128 & 0.0274 & 0.1804 & 0.6378 & 0.0196 & 0.0130 & 0.2766 & 0.1504 & \\
\hline $\mathbf{M}$ & 0.0701 & 0.7224 & 0.0446 & 0.2169 & 0.8851 & 0.0290 & 0.0179 & 0.3082 & 0.1821 & \\
\hline m & 0.0487 & 0.7008 & 0.0202 & 0.1337 & 0.5507 & 0.0122 & 0.0095 & 0.1739 & 0.0914 & \\
\hline \multicolumn{11}{|c|}{ Physical } \\
\hline Years & $\begin{array}{l}\text { Type of } \\
\text { housing }\end{array}$ & $\begin{array}{c}\text { Predominant } \\
\text { housing } \\
\text { material }\end{array}$ & \begin{tabular}{|} 
Predominant \\
material on \\
the floors of \\
the house
\end{tabular} & $\begin{array}{l}\text { Energy } \\
\text { services }\end{array}$ & $\begin{array}{l}\text { Water } \\
\text { supplier }\end{array}$ & $\begin{array}{l}\text { Aqueduct } \\
\text { services }\end{array}$ & $\begin{array}{l}\text { Phone } \\
\text { Services }\end{array}$ & $\begin{array}{l}\text { Internet } \\
\text { services }\end{array}$ & $\begin{array}{l}\text { Cleaning } \\
\text { services }\end{array}$ & LPC \\
\hline 2009 & 0.0267 & 0.6003 & 0.4073 & 0.9878 & 0.9844 & 0.9696 & 0.9019 & 0.0589 & 0.9939 & \\
\hline 2010 & 0.0269 & 0.5725 & 0.5540 & 0.9730 & 0.9574 & 0.9602 & 0.8409 & 0.1079 & 0.9886 & \\
\hline 2011 & 0.0014 & 0.6701 & 0.3460 & 0.9855 & 0.9725 & 0.9349 & 0.8104 & 0.1824 & 0.9392 & \\
\hline 2012 & 0 & 0.6701 & 0.4567 & 0.9690 & 0.9720 & 0.9338 & 0.8146 & 0.2619 & 0.9100 & \\
\hline 2013 & 0.0117 & 0.5830 & 0.4431 & 0.9985 & 0.9649 & 0.9534 & 0.7790 & 0.3052 & 0.9059 & \\
\hline $\begin{array}{l}\text { Relation- } \\
\text { ship } \\
\text { Orien- } \\
\text { tation }\end{array}$ & Positive & Negative & Negative & Negative & Negative & Negative & Negative & Negative & Negative & 0.5295 \\
\hline Subindex & 0.4959 & 0.5216 & 0.5412 & 0.5339 & 0.5238 & 0.5371 & 0.5904 & 0.4950 & 0.5268 & \\
\hline $\mathbf{x}$ & 0.0134 & 0.6192 & 0.4414 & 0.9828 & 0.9702 & 0.9504 & 0.8294 & 0.1832 & 0.9475 & \\
\hline $\mathbf{M}$ & 0.0269 & 0.6701 & 0.5540 & 0.9985 & 0.9844 & 0.9696 & 0.9019 & 0.3052 & 0.9939 & \\
\hline m & 0.0000 & 0.5725 & 0.3460 & 0.9690 & 0.9574 & 0.9338 & 0.7790 & 0.0589 & 0.9059 & \\
\hline
\end{tabular}


MISCELLANEA GEOGRAPHICA - REGIONAL STUDIES ON DEVELOPMENT

Annex 2

\begin{tabular}{|c|c|c|c|c|c|c|c|c|c|c|c|c|}
\hline \multicolumn{13}{|c|}{ Financial } \\
\hline Years & $\begin{array}{c}\text { Homeowner- } \\
\text { ship }\end{array}$ & $\begin{array}{c}\text { Number of } \\
\text { vehicles }\end{array}$ & \begin{tabular}{c|c} 
Number of & $\mathrm{J}$ \\
motorcycles & ho
\end{tabular} & $\begin{array}{c}\text { Job of the } \\
\text { householder }\end{array}$ & \multicolumn{2}{|c|}{$\begin{array}{l}\text { Financial } \\
\text { expenses }\end{array}$} & \multicolumn{2}{|c|}{$\begin{array}{c}\text { Medical } \\
\text { services } \\
\text { expenses }\end{array}$} & \multicolumn{2}{|c|}{$\begin{array}{c}\text { Medication } \\
\text { expenses }\end{array}$} & $\begin{array}{l}\text { Pensions } \\
\text { affiliation }\end{array}$ & LFC \\
\hline 2009 & 0.5508 & 0.0139 & 0.0536 & 0.6173 & \multicolumn{2}{|c|}{0.2685} & \multicolumn{2}{|c|}{0.0744} & \multicolumn{2}{|c|}{0.1002} & 0.0696 & \multirow{10}{*}{0.4745} \\
\hline 2010 & 0.5462 & 0.0182 & 0.0840 & 0.5756 & \multicolumn{2}{|c|}{0.2031} & \multicolumn{2}{|c|}{0.2101} & \multicolumn{2}{|c|}{0.1583} & 0.1672 & \\
\hline 2011 & 0.6483 & 0.0087 & 0.0796 & 0.5629 & \multicolumn{2}{|c|}{0.1375} & \multicolumn{2}{|c|}{0.0796} & \multicolumn{2}{|c|}{0.0791} & 0.0803 & \\
\hline 2012 & 0.5889 & 0.0146 & 0.1302 & 0.5642 & \multicolumn{2}{|c|}{0.2369} & \multicolumn{2}{|c|}{0.2884} & \multicolumn{2}{|c|}{0.3163} & 0.1521 & \\
\hline 2013 & 0.5905 & 0.0118 & 0.1415 & 0.6154 & \multicolumn{2}{|c|}{0.5612} & \multicolumn{2}{|c|}{0.2139} & \multicolumn{2}{|c|}{0.4229} & 0.1605 & \\
\hline $\begin{array}{l}\text { Relationship } \\
\text { Orientation }\end{array}$ & Negative & Negative & Negative & Negative & \multicolumn{2}{|c|}{ Positive } & \multicolumn{2}{|c|}{ Positive } & \multicolumn{2}{|c|}{ Positive } & Negative & \\
\hline Subindex & 0.6204 & 0.5024 & 0.4972 & 0.5553 & & .3398 & & 4620 & 0.3 & & 0.4226 & \\
\hline$x$ & 0.5849 & 0.0134 & 0.0978 & 0.5871 & & .2814 & & 1733 & 0.2 & & 0.1260 & \\
\hline $\mathbf{M}$ & 0.6483 & 0.0182 & 0.1415 & 0.6173 & & .5612 & & 2884 & 0.4 & & 0.1672 & \\
\hline m & 0.5462 & 0.0087 & 0.0536 & 0.5629 & & 1375 & & 0744 & 0.0 & & 0.0696 & \\
\hline & & & & Social & & & & & & & & \\
\hline Years & $\begin{array}{c}\text { People } \\
\text { affiliated with } \\
\text { the subsidized } \\
\text { health regime }\end{array}$ & $\begin{array}{l}\text { Households } \\
\text { participating } \\
\text { in sports } \\
\text { programmes }\end{array}$ & $\begin{array}{c}\text { Number of } \\
\text { Households } \\
\text { participating } \\
\text { in recreational } \\
\text { programmes }\end{array}$ & 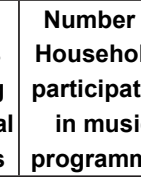 & & $\begin{array}{r}\text { Numb } \\
\text { House } \\
\text { particip } \\
\text { in the } \\
\text { progra }\end{array}$ & \begin{tabular}{l|} 
of \\
olds \\
ting \\
tre \\
mes
\end{tabular} & $\begin{array}{r}\text { Numl } \\
\text { House } \\
\text { partici } \\
\text { in pa } \\
\text { progra }\end{array}$ & $\begin{array}{l}\text { er of } \\
\text { olds } \\
\text { ating } \\
\text { ting } \\
\text { nmes }\end{array}$ & $\begin{array}{r}\mathrm{Nu} \\
\mathrm{Hol} \\
\text { parti } \\
\text { othe } \\
\text { pro }\end{array}$ & $\begin{array}{l}\text { umber of } \\
\text { useholds } \\
\text { icipating in } \\
\text { er types of } \\
\text { ogramme }\end{array}$ & LSC \\
\hline 2009 & 0.4698 & 0.0912 & 0.0193 & 0.0258 & & 0.01 & & 0.0 & & & 0.0105 & \\
\hline 2010 & 0.4521 & 0.0785 & 0.0393 & 0.0224 & & 0.00 & & 0.0 & & & 0.0074 & \\
\hline 2011 & 0.4605 & 0.1302 & 0.0579 & 0.0145 & & 0.00 & & 0.0 & & & 0.0290 & \\
\hline 2012 & 0.4653 & 0.2018 & 0.1169 & 0.0424 & & 0.01 & & 0.0 & & & 0.0087 & \\
\hline 2013 & 0.5417 & 0.1003 & 0.0383 & 0.0029 & & 0.00 & & 0.0 & & & 0.0059 & \\
\hline $\begin{array}{l}\text { Relationship } \\
\text { Orientation }\end{array}$ & Negative & Negative & Negative & Negative & & Nega & & $\mathrm{Neg}$ & tive & & Vegative & 0.6399 \\
\hline Subindex & 0.7121 & 0.6599 & 0.6412 & 0.5271 & & 0.58 & & 0.6 & & & 0.7221 & \\
\hline $\mathbf{x}$ & 0.4779 & 0.1204 & 0.0543 & 0.0216 & & 0.01 & & 0.0 & & & 0.0123 & \\
\hline M & 0.5417 & 0.2018 & 0.1169 & 0.0424 & & 0.01 & & 0.0 & & & 0.0290 & \\
\hline m & 0.4521 & 0.0785 & 0.0193 & 0.0029 & & 0.00 & & 0.0 & & & 0.0059 & \\
\hline & & & & atural & & & & & & & & \\
\hline Years & $\begin{array}{c}\text { Households } \\
\text { without a toilet }\end{array}$ & Energy type & $\begin{array}{l}\text { Rubbish } \\
\text { disposal }\end{array}$ & $\begin{array}{l}\text { Cleanin } \\
\text { services }\end{array}$ & & & & & LN & & & \\
\hline 2009 & 0.0095 & 0.0000 & 0.0009 & 0.9939 & & & & & & & & \\
\hline 2010 & 0.0000 & 0.0042 & 0.0000 & 1.0000 & & & & & & & & \\
\hline 2011 & 0.0014 & 0.0058 & 0.0000 & 1.0000 & & & & & & & & \\
\hline 2012 & 0.0582 & 0.0000 & 0.0071 & 1.0000 & & & & & & & & \\
\hline 2013 & 0.0807 & 0.0015 & 0.0015 & 0.9706 & & & & & & & & \\
\hline $\begin{array}{l}\text { Relationship } \\
\text { Orientation }\end{array}$ & Positive & Positive & Positive & Negative & & & & & 0.43 & & & \\
\hline Subindex & 0.4959 & 0.5223 & 0.3773 & 0.3466 & & & & & & & & \\
\hline $\mathbf{x}$ & 0.0300 & 0.0023 & 0.0019 & 0.9929 & & & & & & & & \\
\hline M & 0.0807 & 0.0058 & 0.0071 & 1.0000 & & & & & & & & \\
\hline m & 0.0000 & 0.0000 & 0.0000 & 0.9706 & & & & & & & & \\
\hline
\end{tabular}


Alcaldía de Medellín 2006, Mapa de Medellín 2006, Available from <http://www.zonu.com/America-del-Sur/Colombia/Antioquia/ Medellin/index.html>. [5 June 2015].

Alcaldía de Medellín 2009, Medellín todos por la vida, Alcaldía de Medellín, Medellín.

Alcaldía de Medellín 2013, Alcaldía de Medellín, Available from: <https://www.medellin.gov.co/irj/go/km/docs/pccdesign/ SubportaldelCiudadano_2/PlandeDesarrollo_0_17/ IndicadoresyEstadsticas/Shared\%20Content/Encuesta\%20 Calidad\%20de\%20Vida/ECV2013/PDFs/08Indicadores. pdf>. [27 April 2015].

Anand, S \& Sen, A 1997, Concepts of human development and poverty: a multidimensional perspective", Human Development Papers 1997, Human Development Report Office, UNDP, New York.

Bicknell, J, Dodman, D \& Satterthwaite, D 2009, Adapting cities to climate change: Understanding and addressing the development challenges, Earthscan, London.

BID 2008, Seguridad Ciudadana, Available from: <www.iadb.org: www. iadb.org/es/impacto-medellin,5678.html>. [2 June 2015].

Boggia, A \& Cortina, C 2010, "Measuring sustainable development using a multicriteria model A case study", Journal of Environmental Management, vol. 91, pp. 2301-2306.

CARE 2015, Care Foundation, Available from: <http://www. pointofcarefoundation.org.uk/Caches/Files/15.03.16\%20 Hospice \%20UK\%20Resilience\%20report\%20PR-\%20 FINAL.pdf>. [30 May 2015].

Carney, D, Drinkwater, M, Rusinow, T, Neefjes, K, Wanmali, S \& Singh, N 1999, Livelihoods approaches compared, Department for International Development, London.

Carney, D 1998, Sustainable rural livelihoods: What contribution can we make?, Department for International Development, London.

Carr, E 2014, "From description to explanation: Using the livelihoods as intimate government (LIG) approach", Applied Geography, vol.52, pp.110-122.

Chambers, R \& Conway, R 1992, 'Sustainable rural livelihoods: Practical concepts for the 21st century', Disussion paper, vol. 296, pp. 1-29.

Comuna Popular, 2014, Comuna Popular, Available from: $<$.comunapopular.org/index.php?option=com content\&view $=$ article\&id=47\&itemid=72>. [2 June 2015].

De la Espriella, C 2007, "Designing for equality: Conceptualising a tool for strategic territorial planning", Habitat International, vol. 31, pp.317-332.

DFID, 1999, Sustainable livelihoods guidance sheets, DFID, London.

Donohue, C \& Biggs, E 2015, "Monitoring socio enviromental change for sustainable development: developing a multidimensional livelihoods index", Applied Geography, vol. 62, pp.391-403.

El Colombiano 2015a, New York Times destaca la transformación de Medellín, Available from: <http://www.elcolombiano. com/new-york-times-destaca-transformacion-de-medellinXI1921110>. [25 May 2015].

El Colombiano 2015b, La ciudad con mayor reducción de tasas de homicidios, Available from: < www.elcolombiano.com; www.elcolombiano.com/medellin-la-ciudad-con-mayorreduccion-de-homicidios-en-los-ultimos-anos-ongLI38094>. [2 June 2015].

El Espectador 2013, Medellinizar, Available from: <http://www. elespectador.com/opinion/medellinizar>. [25 May 2015].
El Espectador 2015, Medellín es una Uva, Available from: <www.elespectador.com; www.elespectador.com/noticias/ nacional/medellin-una-uva-articulo-485272> [2 June 2015].

Forbes 2014, The transformation of Medellin and the surprising company behind it. Available from<www.forbes.com/sites/ ashoka/2014/01/27/the-transformation-of- Medellín- andthe- surprising-compañy-behind-it/>. [15 June 2015].

Foster, J \& Sen, A 1997, On economic inequality after a quarter century. En on economic inequality,Claredon Paperbacks, Oxford.

Fussel, H \& Klein, R 2006, "Climate change vulnerability assessment: an evolution of conceptual thinking" Climatic Change, vol.75, no.3, pp. 301-329.

Heinrichs, D \& Bernet, J 2014, "Public transport and accessibility in informal settlements: Aerial cable cars in Medellín Colombia", Trasportation Research Procedia, vol.4, pp.55-67.

IPC 2010, Preocupación por casos de explotación sexual, Available from: <ww.ipc.org.co/agenciadeprensa/index.php? option=com_content\&view=article\&id=439: preocupacion-enla-comuna-1-de-medellin-por-casos-de-explotacion-sexual \&catid=37: general\&itemid=150>. [5 June 2015]

IPCC 2014, 'Summary for policymakers' in Climate Change 2014, Impacts, Adaptation, and Vulnerability, Cambridge University Press, United Kingdom and New York.

KEI 2005, 'Knowledge economy indicators', Work Package 7, State of the Art Report on Simulation and Indicators, Knowledge Economy Indicators.

Kondyli, J 2010, "Measurement and evaluation of sustainable development A composite indicator for the islands of the North Aegean region, Greece", Environmental Impact Assessment Review, vol. 30, pp.347-356.

Krantz, L 2001, The sustainable livelihoods approach to poverty reduction, Sida, Swedish.

Kumar, R, Murty, H, Gupta, S \& Dikshit, A 2012, "An overview of sustainability assessment methodologies", Ecological indicators, vol.15, pp.281-299.

Londoño, A, Vélez, O \& Rojas, J 2015, "Evaluación del grado de preparación para asumir el reto de la internacionalización de las pymes desde un enfoque integrador de las capacidades dinámicas y la gestión del conocimiento", Espacios, vol. 36, no.7.

Londoño, A 2015, "El enfoque de gobernanza en la evaluación del desarrollo sostenible a escala local (caso del departamento de Antioquia, Colombia)", Revista Mexicana de Ciencias Agrícolas, no. 12, pp. 257-263.

Lotero, J 2003, "Las relaciones del desarrollo económico con la geografía y el territorio: una revisión", Borradores del CIE, pp.1-35.

Maxneef, M 2007, Human scale development: conception, application and further reflections, Available from < http:// www.area-net.org: http://www.area-net.org/fileadmin/user upload/papers/Max-neef_Human_Scale_development. pdf>. [14 March 2015].

Ortiz, W 2011, Los parques bibliotecas en la ciudad de Medellín, Medellín.

Pelling, M 2003, The vulnerability of cities. Natural disasters and social resilience, Earthscan, London.

Rebotier, J 2012, "Vulnerability conditions and risk representations in Latin-America: Framing the territorializing urban risk", Global Environmental Change, vol. 22, pp. 391-398.

Romero, P, Hughes, S, Qin, H, Hardoy, J, Rosas, A, Borquez, R \& Lampis, A 2014," Scale, urban risk and adaptation capacity in neighborhoods of Latin American cities", Habitat International, vol.42, pp.224-235. 
Ruta, N 2014, La transformación de Medellín se visualiza durante el foro urbano mundial, Available from: <http:// rutanmedellin.org/es/actualidad/noticias/item/latransformacion-de-medellin-se-visualiza-durante-el-forourbano-mundial-140408>. [25 May 2015].

Schuschny, A. \& Soto, H 2009, Guía metodológica Diseño de indicadores compuestos de desarrollo sostenible, Naciones Unidas- CEPAL, Santiago de Chile.

Scoones, I 1998, 'Sustainable rural livelihoods: A framework for analysis. In IDS', Working Paper 72, IDS, Brighton, UK.

Solesbury, W 2003, Sustainable livelihoods: A case study of the evolution of DFID policy. In Overseas Development Institute, Working Paper 217, Overseas Development Institute, London, UK.

Sepúlveda, S 2008, Metodología para estimar el nivel de desarrollo sostenible en teritorios, IICA, San José.
Sepúlveda, S, Chavarría, H \& Rojas, P 2005, Metodología para estimar el nivel de desarrollo sostenible de los territorios rurales (El Biograma), IICA, San José.

UNDP 1992, United Nations Conference on Environment \& Development, United Nations, Rio de Janeiro.

Velez, O 2015, "Adaptación ciudadana a las Tecnologías de Información y Comunicación en "Smart Cities" desde una perspectiva de la educación para el desarrollo sostenible, caso Medellín-Colombia", Revista Mexicana de Ciencias Agrícolas, no.7, pp. 487-494.

WCED 1987, Our common future: The Report of the Wolrd Commission on Enviroment and Development, Oxford Universiy Press, New York. 